\title{
The Influence of Manganese on Elimination Harmful Effect of Iron with Different Level of Iron in the Alloy Based on Al-Si-Mg
}

Radka Podprocká, Dana Bolibruchová

Department of Technological Engineering, Faculty of Mechanical Engineering, University of Zilina, Univerzitna 8215/1, 01026 Žilina. Slovak Republic. E-mail: radka.podprocka@fstroj.uniza.sk, danka.bolibruchova@fstroj.uniza.sk.

Manganese is the most widely used and it can modify the $\beta$-Fe platelet-like morphology to more compact and harmless forms (i.e. Chinese script, skeleton-like and/or polyhedral $\alpha$-Fe phase) Furthermore, the Mn and Fe content can influence the type, the size and the ratio of different $\mathrm{Fe}$ intermetallic compounds. The present study investigates the effect of manganese concentration on the formation of iron compounds in an AISi7Mg0.3 with levels of iron 0.3 and $0.7 \mathrm{wt}$. \%. The manganese was ranking in amount of $0.1,0.2,0.6 \mathrm{wt}$. \%. The morphology iron intermetallic phases has been investigated using cooling curve analysis, optical microscopy and scanning electron microscopy (SEM). Can be concluded, that increased amount of manganese lead to decrease the temperature of solidification iron rich phase $\left(\mathrm{TAl}_{5} \mathrm{FeSi}\right)$ and reduction these particles.

Keywords: manganese, iron rich phases, $\mathrm{AlSi} 7 \mathrm{Mg} 0.3$ alloy

\section{References}

[1] TAYLOR, J.A. (2012). Iron-containing intermetallic phase in Al-Si based casting alloys. In Procedia Materials Science. 2012. Vol 1, pp. 19-33.

[2] SHABESTARI S.G., (2004). The effect of iron and manganese on the formation of intermetallic compoundsin aluminium-silicon alloys. In: Materials Science and Engineering A383, 289-298

[3] DINNIS, C. M. et al., (2005). As-cast morphology of iron-intermetallics in Al-Si foundry alloys, Scripta Materialia 53 (8), pp. 955-958.

[4] BIDMESHKI et. al. (2016). Effect of Mn addition of Fe-rich intermetallics morphology and dry sliding wear investigation of hypereutectic Al-17,5\% Si. Journal of Materials Research and Technology. 5 (3), 250-258

[5] FORTINI, et. al. (2016). On influence of Mn and Mg additions on tensile properties, microstructure and quality index of the A356 aluminum foundry alloy. 21st European Conference on Fracture. Procedia Structural Integrity. 2, 2238-2245.

[6] BRUNA, M,. (2016). Hot tearing evaluation of Al. In: Manufacturing Technology, Vol. 16, No. 2, pp. 323-327, ISSN 1213-2489.

[7] PASTIRČÁK, R. (2014). Effect of low pressure application during solidification on microstructure of AlSi alloys. In: Manufacturing Technology. ISSN 1213-2489. Vol. 14, No. 3 (2014), p. 397-402.

[8] CAO, X. \& CAMPBELL, J. (2006). Morphology of $\mathrm{Al}_{5} \mathrm{FeSi}$ Phase in Al-Si Cast Alloys. Materials Transactions. 47(5), 1303-1312.

[9] BOLIBRUCHOVÁ, D., ŽIHALOVÁ, M. (2013). Possibilities of iron elimination in aluminium alloys by vanadium. In: Manufacturing Technology, ISSN 1213-2489, Vol. 13, No. 3, pp. 289-296.

[10] ZHANG A KOL. (2013). Effect of the $\mathrm{Mn} / \mathrm{Fe}$ ratio and cooling rate on the modification of Fe intermetallic compounds in cast A356 based alloy with different Fe contents. Materials Transactions. 54 